\title{
Tradisi Sebagai Sumber Penalaran Hukum Islam (Studi Paradigma Ahli Sunnah Wal Jama'ah)
}

\author{
Agus Hermanto
}

Mahasiswa S3 UIN Raden Intan Lampung

Email : gusher.sulthani@gmail.com

\begin{abstract}
"Tradition ('urf) as a Source of Islamic Law Reasoning; Study Paradigm Sunnah wal Jama'ah Experts in Developing Local Culture "One tradition ('urf) can be used as a source of Islamic law if it does not conflict with Personality', and not all traditions can be used as a source of Islamic law. Tradition itself is an activity that is repetitive, but does not violate the order of Shariah, the tradition is not sharia, but branches (furu ') in order to address or even develop Islamic teachings amaliyah (amaliy) or often called (bid'ah hasanah) .The ahlu sunnah wal jama'ah develop local culture such as tahlilan, yasinan, istighasah, tawashul or the like in the implementation of the (practice) there is no standard rules, but it is the implementation of more emphasis on reading tahlil (la ilaha ilallah), or yasinan namely reading yasin as the heart of a Qur'an, namely istighasah appeal help in Allah and not in others, and that is ihtiram tawashul to teachers as washilah in a prayer, and of course this is bid'ah hasanah not teaching out of Personality '
\end{abstract}

Keywords: Tradition, 'urf, Ahl Sunnah Wa al-Jama'ah

\section{Abstrak}

"Tradisi ('Urf) Sebagai Sumber Penalaran Hukum Islam; Studi Paradigma Ahli Sunnah wal Jama'ah dalam Mengembangkan Budaya Lokal" Suatu tradisi ('urf) dapat dijadikan sumber hukum Islam apabila tidak bertentangan dengan syara', dan tidak semua tradisi dapat dijadikan sebagai sumber hukum Islam. Adapaun tradisi itu sendiri merupakan suatu kegiatan yang berulang-ulang, namun tidak melanggar tatanan syari'ah, tradisi bukan syari'ah, namun sebgai cabang (furu') dalam rangka menyikapi atau bahkan mengembangkan ajaran Islam secara amaliyah atau sering 
disebut (bid'ah hasanah). Para ahlu sunnah wal jama'ah mengembangkan budaya lokal tersebut seperti tahlilan, yasinan, istighasah, tawashul atau sejenisnya secara pelaksanaan (praktek) tidak ada aturannya yang baku, namun justru pelaksanaan tersebut lebih menekankan kepada bacaan tahlilnya (la ilaha ilallah), atau yasinan yaitu bacaan yasinnya sebagai qalbu qur'an, istighasahnya yaitu memohon pertolongan kepada Allah dan bukan selainnya, serta tawashul yaitu bentuk ihtiram kepada guru sebagai washilah dalam sebuah do'a, dan tentunya inilah bid'ah hasanah bukan ajaran yang keluar dari syara'.

Kata Kunci: Tradisi, 'Úrf, Ahl Sunnah Wa al-Jama'ah

\section{A. Pendahuluan}

\section{Latar Belakang}

Adat Istiadat atau tradisi tertentu bukanlah sebuah syari'ah, namun sebuah furu' dalam fikih yang dikembangankan, yang sering disebut dengan 'urf. Tidak semua budaya atau adat istiadat dapat dijadikan sebagai dalil hukum Islam, namun hanya tradisi yang baiklah yang dapat dijadikan sebagai dalil hukum, karena tradisi yang baik tersebut sudah tentu tidak keluar dari dalil syara'.

Dalam hal ini Ahl al-Sunnah wa al-Jama'ah mengembangkan tradisi-tradisi lokal yang tidak bertentangan dengan hukum Islam atau syara', diantaranya adalah tahlilan, yasinan, istighasah dan sebagainya. Karena hal ini merupakan sebuah tradisi baik yang dilakukan oleh sebagian besar masyarakat Islam di Indonesia, dikatakan tidak bertentangan karena memang sebenarnya hanya sebuah wadah untuk dapat bersama-sama berdo'a, bertahlil dan bertahmid kepada Allah Swt., dan bukan yang lainnya, kecuali bagi oknum yang menyalah artikan, yang kemudian dijadikan sebagai lahan untuk berfoya-foya.

'Urf (tradisi) yang menjadi budaya lokal masyarakat Indonesia, yang bersifat perbuatan (amaliy), karena memang sudah dilakukan oleh para penyiar agama Islam di Nusantara yang menjadikannya budaya ini mendarah daging dan mengakar yang seakan tak terlewatkan yang telah ditanamkan oleh para ulama' terdahulu sebagai media dakwah. 


\section{Rumusan Masalah}

Bagaimanakah Tradisi Sebagai Sumber Penalaran Hukum Islam (Studi Paradigma Ahli Sunnah Wal Jama'ah)?

\section{B. 'Urf (Tradisi Baik)}

'Urf secara etimologi berarti sesuatu yang dipandang baik, yang dapat diterima akal sehat. Menurut kebanyakan sahabat, 'urf dinamakan juga 'adat sebab perkara yang sufah dikenal itu berulang kali dilakukan manusia. ${ }^{1}$ 'Urf adalah kebiasaan atau adat istiadat yang sudah turun temurun keberlakuannya di dalam masyarakat. 'Urf dimaksud ada yang sesuai dengan ajaran Islam, atau tidak bertentangan dengan ajaran agama Islam biasa disebut dengan adat (tradisi biak). ${ }^{2}$

'Urf (kebiasaan masyarakat) adalah sesuatu yang berulang-ulang dilakukan oleh masyarakat daerah tertentu, dan terus-menerus dijalani oleh mereka, baik hal tersebut dilakukan sepanjang masa atau dalam masa tertentu saja. Kata "sesuatu" mencakup sesuatu yang baik; berlaku juga yang bersifat perkataan (qauliy) dan hal yang bersifat perbuatan (fi'liy). Ungkapan "masyarakat" mengekslusi (menyingkirkan) kebiasaan individual dan kebiasaan sekelompok kecil orang. Ungkapan "daerah tertentu" menunjukkan úrf amm.

'Adat adalah perkara yang berulang-ulang dan terusmenerus terjadi, yang bukan merupakan hubungan yang rasional. Ungkapan "perkara yang berulang-ulang dan terusmenerus terjadi" menunjuk kepada segenap kadar cakupannya, yakni baik yang bersifat kolektif maupun individual, baik yang bersifat perkataan maupun perbuatan, baik yang bersifat positif-konstruktif maupun yang bersifat

1 'Adat sebenarnya lebih luas daripada 'urf, sebab adat biasanya terdiri atas adat perorangan atau bagi orang tertentu, sehingga hal ini tidak bisa dinamakan 'urf. Dan kadang-kadang terdiri dari adat masyarakat. Maka inilah yang disebut dengan 'urf, baik 'urf itu bersifat khusus atau umum. Chairul Umam dkk, Ushul Figh I, (Bandung: Pustaka Setia, 2008), h. 159

Abdul Wahab Khalaf, Kaidah-Kaidah Hukum Islam, diterjemahkan oleh Noer Iskandar, (Jakarta: Rajawali Press, 1996), h. 134 
negatif-destruktif. Ungkapan "yang bukan merupakan hubungan yang rasional, seperti hukum kausalitas, hukum gravitasi, dan hukum perubahan energi. ${ }^{3}$

Para ulama' madzhab fikih, pada dasarnya sepakat untuk menjadikan 'urf secara global sebagai dalil hukum Islam (hujjah syar'iyyah). Perbedaan diantara mereka terjadi mengenai limitasi dan lingkup aplikasi dari 'urf itu sendiri. Mengenai kehujahan 'urf terdapat perbedaan pendapat dikalangan ulama' usul fikih, yang menyebabkan dua golongan diantara mereka, yaitu:

a. Golongan Hanafiyah dan Malikiyah berpendapat bahwa 'urf adalah hujah untuk menetapkan hukum sebagaimana penjelasan surat al-A'raf ayat 199. Ayat ini bermaksud bahwa 'urf adalah kebiasaan manusia, dan apa-apa yang sering mereka lakukan (yang baik).

b. Golongan Syafi'iyah dan Hanbaliyah, keduanya tidak menganggap 'urf itu sebagai hujjah atau dalil hukum syar' $i .{ }^{5}$

\section{Ahl al-Sunnah Wa al-Jama'ah}

Sunnah menurut bahasa berarti sejarah (perjalanan hidup) dan jalan (metode) yang ditempuh. Secara istilah, sunnah ada beberapa pengertian, yaitu:

1. Menurut ulama hadits, yaitu apa yang datang dari Rasulullah, perkataan perbuatan, taqrir/penetapan, pendiaman atau yang ingin dikerjakan beliau.

2. Menurut ulama usul fikih, ialah setiap yang datang dari Rasulullah baik perintah, perkataan, perbuatan maupun taqrir beliau selama bukan al-Qur'an dan bisa menjadi sebuah dalil dari hukum syar'i.

3. Menurut ulama fikih, ialah sesuatu yang jelas atau tegas dari Rasulullah, namun tidak berhukum wajib, sunah dalam artian ini sinonim dengan mandub atau mustahab.

Kata jama'ah secara bahasa berarti kelompok, bersatu atau lawan dari kata pecah belah, adapun secara syara'

${ }^{3}$ Ahmad bin Ali al-Mubaraki, al- 'Urf wa Atsaruhu fi al-Syari'ah wa al-Qonun, dikutip oleh Asmawi, (Jakarta: Amzah, 2011), h. 161-162

${ }^{4}$ Ibid.

${ }^{5}$ Chairul Umam dkk, Ushul Fiqh I, Op.Cit., h. 166 
adalah dari beberapa hadits tentang jama'ah, bahwa ahl jama'ah adalah orang yang mengikuti jama'ah. Sebagaimana beberapa pendapat para ulama tersebut:

1. Yang dimaksud dengan jama'ah adalah generasi sahabat.

2. Yang dimaksud jama'ah adalah para ulama mujtahidin baik dari kalangan ulama ahli hadits, ulama fikih dan ulama lain, artinya ulama mujtahidin menjadi panutan masyarakat.

3. Jama'ah juga berarti ijma', yaitu kesepakatan umat Islam dalam suatu masalah tertentu, bila seluruh umat Islam telah mengadakan ijma' maka wajib diikuti, orang yang tidak mengikuti bukanlah ahli sunnah wal jama'ah.

4. Jama'ah juga berarti kelompok mayoritas (sawad al$a^{\prime}$ dham), jika suatu telah diyakini dan dijalankan oleh umat Islam.

5. Makna jama'ah adalah pemerintahan negara Islam/ khilafah Islamiyyah dengan seorang Imam/kholifah.

Maka makna ahlu sunnah wal jama'ah sebagai kata majmu' adalah orang-orang yang mengikuti aqidah Islam yang benar, komitmen dengan manhaj Rasulullah, sahabat, tabi'in, tabi' tabi'in dan generasi yang mengikuti mereka dengan baik. ${ }^{6}$ Ahlu sunnah wal jama'ah merupakan akumulasi pemikiran keagamaan dalam berbagai bidang yang dihasilkan para ulama' untuk menjawab persoalan yang muncul pada zaman tertentu. Karenanya, proses terbentuknya ahlu sunnah wal jama'ah sebagai suatu faham atau madzhab membutuhkan jangka waktu yang panjang. Seperti diketahui, pemikiran keagamaan dalam berbagai bidang, seperti ilmu tauhid, fikih atau tasawuf, terbentuk tidak dalam satu masa, tapi muncul bertahap dan dalam waktu yang berbeda. ${ }^{7}$

Ahl al-Sunnah wa al-Jama'ah, terbagi dalam dua madzhab, yaitu ahl ra'yi wa ahl hadits:

a. Ahl Ra'yi, madzhab ini lebih banyak menggunakan akal (nalar) dalam berijtihad, seperti Imam Abu Hanifah. Beliau adalah seorang Imam yang rasional, yang

${ }^{6}$ Nahdhatul Ulama, Faham Keagamaan dan Ideologi Kenegaraan Nahdhatul Ulama', (Mojokerto: PC Nahdhatul Ulama' Kabupaten Mojokerto, 2006), h. 2-4

${ }^{7}$ Nuril Huda, Aswaja, Op.Cit., h. 9 
mendasarkan ajarannya dari al-Qur'an dan al-Sunnah, ijma', qiyas serta istihsan. Beliau sendiri tidak mengarang kitab, tetapi muridnyalah yang menyebarkan fahamnya, kemudian ditulis dalam kitab-kitab mereka. Madzhab ini berkembang dari Turki, Afganistan, Asia Tengah, Pakistan, India, Irak, Brazil, Amerika Latin dan Mesir.

b. Ahl Hadits, madzhab ini lebih banyak menggunakan hadits dalam berijtihad daripada menggunakan akal, yang penting menggunakan hadits yang digunakan itu shahih. yang termasuk madzhab ini adalah:

1) Madzhab Maliki, madzhab ini dibina oleh Imam Malik bin Anas. Ia cenderung kepada ucapan dan perbuatan (praktek Nabi Muhammad Saw., dan praktek para Sahabatnya serta Ulama Madinah. Madzhab ini berkembang di Afrika Utara, Mesir, Sudan, Quwaid, Qatar dan Bahrain.

2) Madzhab Syafi'i, madzhab ini mengikuti Imam Syafi'i, beliau adalah murid Imam Malik yang pandai. Beliau membina madzhabnya antara ahli ra'yi dan ahli hadits (moderat), meskipun dasar pemikirannya lebih dekat kepada metode ahlu hadits. Madzhab syafi'i berkembang di Mesir, Siria, Pakistan, Saudi Arabia, India Selatan, Muangtai, Malaysia, philipina dan Indonesia.

3) Madzhab Hanbali, madzhab ini menganut Imam Ahmad bin Hanbal. Ia banyak menitik beratkan kepada hadits dalam berijtihad dan tidak menggunakan ra'yu dalam berijtihad kecuali dalam keadaan darurat, yaitu ketika tidak ditemukan hadits, walaupun hadits dha'if, yang tidak terlalu dha 'if, yaitu hadits dha' if yang tidak diriwayatkan oleh pembohong. Madzhab ini berkembang di Saudi Arabia, Syiria dan beberapa negeri di bagian Afrika.

4) Madzhab Dhahiri, madzhab yang mengikuti Imam Daud bin Ali. madzhab ini lebih cenderung kepada dhahir nash dan berkembang di Spanyol pada abad V H. oleh Ibnu Hazm (wafat 456 77H./1085M.) sejak itu, 
madzhab ini berangsur-angsur lenyap sampai sekarang. ${ }^{8}$

\section{Bid'ah dalam Agama}

Jika seorang muslim berhadapan dengan hadit-hadits Rasulullah Saw., dan ia ingin ibadah kepada Allah denganny, maka sebelum mengamalkan hadits-hadits tersebut, dia harus memahami hal-hal yang merupakan kaidah (dalam memahami) hadits itu, agar pemahamannya benar dan pengamalannya menjadi petunjuk (terarah). Ketika Rsulullah Saw., mengucapkan suatu hadits atau beramal pada suatu amalan, sesungguhnya beliau menghendaki maksud tertentu dari ucapan dan amalan tersebut, sehingga tidak ada perbedaan perbedaan yang kontadiktif antara lafadz hadits (tekstual) dan maknanya dari keterangan hadits tersebut, karena jika hadits difahami dengan salah satu diamalkan tidak sesuai dengan hadits itu, niscaya akan turun wahyu untuk meluruskan (amalan yang salah itu) dan mengoreksinya. ${ }^{9}$

Bid'ah adalah sesuatu yang diciptakan (ciptaan baru) yang belum pernah ada contohnya, baik itu perbuatan terpuji maupun ucapan tercela. Adapun menurut pengertian syara, para ulama berbeda pendapat dalam memberikan pengertian tentang arti bid'ahtersebut dan ada yang mempersempitnya, dalam kata lain, ada yang bersifat lunak dan ada juga yang bersifat keras, ${ }^{10}$ Sehingga tidak memberikan ruang ijtihad bahwa unsur-unsur budaya bisa dijadikan sebagai sarana dakwah.

Adapun ulama yang memberikan pengertian sempit dan tidak begitu radikal terhadap bid'ah adalah Ibnu Rajab, Ibnu Hajar al-Astqallani, al-Zarkasyi dan sebagainya. Adapun

${ }^{8}$ Huzaimah Tahido Yanggo, Pengantar Perbandingan Madzhab, (Ciputat: Gaung Persada Press, 2011), h. 84-85. Dedi Supriyadi, Perbandingan Madzhab dengan Pendekatan Baru, (Bandung: Pustaka Setia, 2008), h. 101-112

9 Anis bin Ahmad bin Thahir, Dhawabit Muhimmah li Husni Fahmi al-Sunnah, diterjeahkan oleh Abu Abdirrahman Mukti 'Ali Abdul Karim, (Bogor: Pustaka Imam Al-Syafi'i, 2004), h. 6-7

${ }^{10}$ Asyhari Marzuki,Wawasan Islam, Op.Cit., h. 92-93 
yang sangat radikal adalah al-Syatibi. ${ }^{11}$ Sepertihalnya dijelaskan bahwa sesungguhnya yang paling benar adalah kitabullah dan petunjuk yang paling baik adalah petunjuk Muhammad Saw., dan sejelek-jeleknya perkara adalah perkara yang baru dalam agama adalah bid'ah dan setiap bid'ah adalah kesesatan dan setiap kesesatan (tempatnya) di neraka.

Seperti perkataan Ibnu Rajab: "Perkataan Beliau Saw., (كلّ بدعة ضلالة ) "Setiap bid'ah adalah kesesatan” (adalah kalimat yang ringkas namun memiliku arti yang sangat luas). Yang meliputi segala sesuatu, kalimat itu merupakan salah satu merupakan pokok-pokoh ajaran agama yang agung".

Berkata Ibnu Hajar: "perkataan beliau Saw., "Setiap bid'ah adalah kesesatan", merupakan suatau kaidah agama yang menyeluruh, baik yang secara tersirat maupun tersirat. Adapun makna tersurat bahwa seakan-akan beliau berkata: "Hal ini bid'ah hukumnya dan setiap bid'ah itu adalah kesesatan", sehingga ia tidak masuk dalam agama ini, sebab agama itu semuanya adalah petunjuk. Oleh karena itu, apabila terbukti dalam suatu hal tertentu hukumnya bid'ah, maka berlaku dua dasar hukum itu (setiap bid'ah adalah sesat setiap kesesatan bukan dari agama), sehingga kesimpulannya adalah tertolak".

Muhammad bin Shahih al-Utsaimin berkata bahwa ungkapan yang bersifat umum ini dan menyeluruh, karena diperkokoh dengan kata yang menunjukkan makna menyeluruh dan umum yang paling kuat, yaitu kata "setiap". Maka setiap apasaja yang diklaim sebagai bid'ah hasanah adalah sesat. Maka tak ada sedikit peluang bagi ahlu bid'ah untuk menjadikan bid'ah mereka itu sebagai bid'ah hasanah. $^{12}$

Ulama yang bersifat lunak dalam memahai bid'ah diawali oleh ulama-ulama besar seperti al-Syafi'i, Imam

${ }^{11}$ Ibid., h. 93

12 Abdul Qayyum Muhammad al-Sahibani, al-Lam'u fi al-Radi 'Ala Muhsiniy al-Bid'ah, diterjelahkan oleh Abu Hafh Muhammad Syarif Asbi Al-Anboniy, (Solo: al-Tibyan, 2003), h. 26-18. Lihat juga Abdullah bin Abdul Aziz al-Tuwaijiry, al-Bida'i al-Hauliyyah wa Fatwa Tata'allaq bi al-Maulid al-Nabawi, diterjemahkan oleh Munirul Abidin, (Jakarta: Daril Falah, 2007), h. 164-164 
Ghazali, Syaikh Dahlawi, Ibnu Hazm dan sebagainya. ${ }^{13}$ Dalam kitab Risalah Ahlussunah Wal Jama'ah karya Hasyim Asy'ari, istilah bid'ah itu disandingkan dengan istilah sunnah. Seperti dijelaskan oleh Syaikh Zaruq dalam kitab 'Uddatul Murid, kata bid'ah secara syara' adalah muncul perkara baru dalam agama yang kemudian mirip dengan bagian ajaran agama itu, padahal bukan darinya, baik formal maupun hakekatnya. Hal ini sesuai dengan hadits Rasulullah Saw., "Barang siapa yang memunculkan perkara baru dalam urusan kami (agama) yang bukan bagian dari agama itu, maka perkara tersebut ditolak". Nabi juga bersabda: "Setiap perkara baru adalah bi 'ah".

Menurut para ulama, makna kedua hadits ini bukan berarti semua perkara yang baru adalah urusan agama tergolong bid'ah, karena mungkin ada perkara baru dalam agama namun masih sesuai dengan ruh syari'ah atau salah satu cabangnya (furu').

Bid'ah dalam arti lain, adalah sesuatu yang baru yang tidak ada sebelumnya, sebagaimana firman Allah Swt., sebagai berikut:

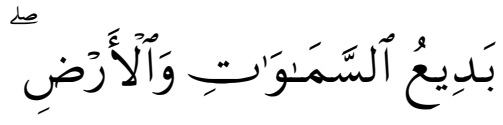

Artinya: "Allah Pencipta langit dan bumi". (QS. alBaqarah: 117).

Adapun bid'ah dalam hukum Islam adalah segala sesuatu yang diada-adakan oleh ulama yang tidak ada pada zaman Nabi Muhammad Saw., timbul suatu pertanyan, apakan segala sesuatu yang diada-adakan oleh ulama setelah Nabi adalah jelek, mana tentu jawabannya belum tentu semua perkara itu disebut bid'ah.

Imam Syafi'i mengatakan sebagai berikut:

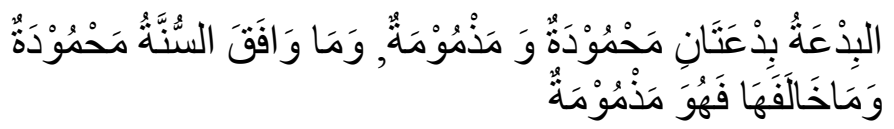

${ }^{13}$ Asyhari Marzuki,Wawasan Islam, Op.Cit., h. 93 
Artinya: "Bid'ah ada dua, bid'ah terpuji dan bid'ah tercela, bid'ah yang sesuai dengan sunnah itulah bid'ah yang terpuji, dan bid'ah yang bertentangan dengan sunnah itulah bid'ah yang tercela".

Bid'ah dibagi menjadi dua, yaitu bid'ah hasanah dan bid'ah dhalalah (yang buruk) atau tercela. Atas dasar ini, bid'ah meliputi semua kejadian yang terjadi setelah Rasulullah Saw., dan masa Khulafa'u Rasyiddin. ${ }^{14}$ Sayyidina Umar Ibnu Khattab, telah mengadakan shalat tarawih 20 rakaat berjamaan dengan rakaat dua puluh yang diimami oleh sahabat Ubay bin Ka'ab beliau berkata:

Artinya: "Sebagus bid'ah itu adalah ini".

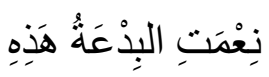

Imam Ghazali dalam kitabnya Ihya' 'Ulumuddin-nya tentang "al-Aqlu 'ala al-sigharah" berkata: "Mengenai perbuatan-perbuatan yang muncul setelah Rasulullah Saw., tidak semuanya dilarang. Tetapi, yang dilarang adalah bid'ah yang bertentangan dengan sunah tsabitah (sunnah yang tetap), dan bid'ah yang dilarang oleh syara', padahal 'illat (alasannya) asih ada. Namun kadang bid'ah ini menjadi wajib dalam beberapa hal, bila illah atau sebabnya berubah.

Adapun al-Dahlawi dalam Syarh al-Misykat menulis: "Ketahuilah bahwa segala sesuatu yang muncul setelah Nabi adalah bid'ah. Dan semua bid'ah yang sesuai dengan dasardasar dan kaidah sunnah Rasulullah atau dapat diqiyaskan dalam sunnah adalah bid'ah hasanah. Sedang yang bertentangan dengan syari'ah atau sunnah disebut dengan bid'ah sayyi'ah atau dhalalah.Izzuddin Ibnu Abd al-Salam dan Abu Syamah juga cenderung pada pendapat ini.

Adapun Ibnu Hazm dari adzhab Dhahiri, mendefinisikan bid'ah sebagai sesuatu yang tidak dilarang dalam al-Qur'an dan tidak pula berasal dari Rasulullah Saw., hanya saja ada tiga hal yang perlu dicermati. Diantaranya ada bid'ah yang pelakunya mendapatkan pahala dan diterima alasannya (atas perbuatan itu) karena kebaikan yang

${ }^{14}$ Asyhari Marzuki,Wawasan Islam, Op.Cit., h. 94 
dimaksudkannya. Ada juga bid'ah yang pelakunya mendapat pahala dan merupakan perbuatan baik.

Kembali kepada hadits Nabi Muhammad Saw., yang menjelaskan adanya bid'ah hasanah dan bid'ah sayyi'ah sebagai berikut:

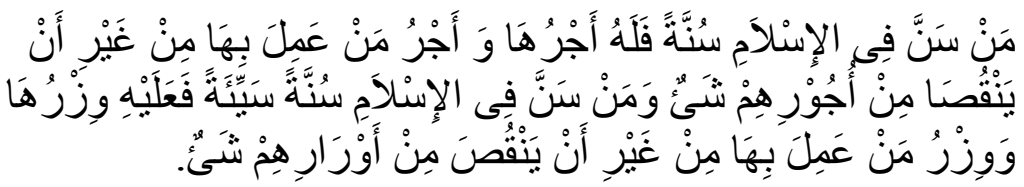

Artinya: "Barang siapa yang mengada-adakan sesuatu yang baik dalam Islam maka ia akan mendapatkan pahala orang yang turut mengerjakannya dengan tidak mengurangi dari pahala mereka sedikitpun, dan barang siapa yang mengada-adakan suatu cara yang jelek, akan mendapatkan dosa dan dosa-dosa orang yang ikut mengerjakan dengan tidak mengurangi dosa-dosa mereka sedikitpun.

Apa yang dimaksud dengan segala bid'ah itu adalah sesat, dan segala kesesatan itu masuk neraka.

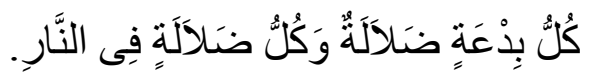

Artinya: "Setiap bid'ah adalah sesat dan setiap kesesatan itu di neraka".

Ketika difahami dengan balaghah, menurut ilmu balaghah. Setiap benda pasti mempunyai sifat. Tidak mungkin ada benda yang tidak mempunyai sifat. Sifat itu bisa bertentangan seperti baik dan buruk, panjang dan pendek, gemuk dan kurus. Mustahil ada benda dalam satu waktu dan satu tempat mempunyai dua sifat yang bertentangan. Kalau dikatakan benda itu baik mustahil dalam waktu dan tempat yang sama dikatakan jelek; kalau si A dikatakan berdiri, mustahil dalam satu waktu ia dikatakan duduk.

Bid'ah itu kata benda, dan karena itu tentu mempunyai sifat. Tidak mungkin ia tidak mempunyai sifat, mungkin saja ia bersifat baik dan mungkin saja ia bersifat buruk. Sifat tersebut tidak ditulis dan tidak disebutkan dalam hadits di

${ }^{15}$ Ibid., h. 94-95 
atas. Dalam ilmu balaghah dikatakan (حذف الصفة على الموصوف) "membuang sifat dari benda yang berbeda". Seandainya kita tulis sifat bid'ah maka terjadi dua kemungkinan; kemungkinan pertama

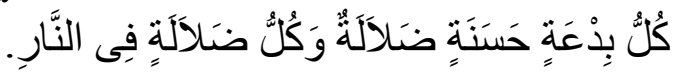

Artinya: "Setiap bid'ah yang baik adalah sesat dan setiap kesesatan itu di neraka".

Hal ini tidak mungkin, bagai mana sifat baik dan sesat terkumpul dalam satu benda serta dalam satu waktu dan tempat yang sama, hal itu tentu mustahil, maka bisa dipastikan kemungkinan yang kedua.

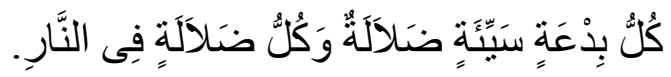

Artinya: "Setiap bid'ah yang jelek adalah sesat dan setiap kesesatan itu di neraka".

Maka jelek dan sesat sepadan (pararel), tidak bertentangan, hal ini terjadi pula dalam al-Qur'an, Allah telah membuang sifat kapal dalam firman-Nya.

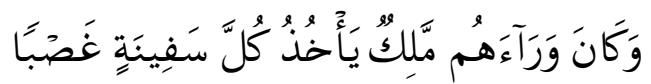

Artinya: "Karena di hadapan mereka ada seorang raja yang merampas tiap-tiap bahtera”. (QS. al-Kahfi: 79).

Dalam ayat tersebut Allah tidak menyebutkan kapal baik ataukah kapal buruk; karena yang jelek tidak akan diambil oleh Raja. Maka lafadz (كلّ سفينة) sama dengan ( كلّ () (بدعة) tidak disebut sifatnya, walaupun pasti punya sifat, ia kapal yang baik ( كلّ سفينة حسنة). Selain itu, ada pendapat lain tentang bid'ah dari Syaikh Zaruq, seperti yang dikutip Hasyim Asy'ari. Menurutnya, ada tiga norma untuk menentukan, apakah perkara baru tersebut termasuk bid'ah atau tidak, yaitu:

1. Jika perkara baru itu didukung oleh sebagian besar syari'ah dan sumbernya, maka perkara tersebut bukan merupakan bid'ah. Namun jika tidak didukung sama sekali dari segala sudut, maka perkara tersebut bathil dan sesat. 
2. Diukur dari kaidah-kaidah yang digunakan para imam dan generasi salaf yang telah mempraktekkan ajaran sunnah. Jika perkara tersebut bertentangan dengan dengan perbuatan para ulama, maka dikatagorikan sebagai bid'ah. Jika para ulama masih berselisih pendapat tentang mana yang masih dianggap ajaran usul (inti) dan mana yang dianggap furu' (cabang), maka harus dikembalikan pada usul dalil yang mendukungnya.

3. Setiap perbuatan ditakar dengan perbuatan hukum adapun rincian hukum dalam syara' ada enam, yaitu wajib, sunah, haram, makruh, khilaful aula, dan mubah. Setiap hal yang termasuk dalam salah satu hukum itu, berarti bisa didefinisikan dalam status hukum tersebut. Namun jika tidak demikian maka dianggap bid'ah.

Syaikh Zaruq membagi bid'ah dalam tiga macam, yaitu:

1. Bid'ah sharihah (yang jelas dan terang, yaitu bid'ah yang tidak memiliki dasar syar'i, seperti wajib, sunah, makruh dan yang lainnya. Menjalankan bid'ah ini berarti mematikan tradisi dan menghancurkan kebenaran. Jelas bid'ah ini merupakan bid'ah paling jelek. Meski bid'ah ini memiliki seribu sandaran dari hukum-hukum asal atau furu', tetapi tidak ada pengaruhnuya.

2. Bid'ah idhafiyah (relasional), yaitu bid'ah yang disandarkan pada suatu praktek tertentu. Seandainyapun praktek itu telah terbatas dari unsur bid'ah tersebut, maka tidak dapat diperdebatkan apakah ia tergolong sebagai sunah atau bukan bid'ah.

3. Bid'ah khilafi (bid'ah yang diperselisihkan), yaitu bid'ah yang memiliki dua sandaran utama yang sama-sama kiat argumentasinya. Maksudnya dari dua sandaran utama tersebut, bagi yang cenderung mengatakan itu sunnah, maka bukan bid'ah. Tapi yang melihat dari sandaran utama itu termasuk bid'ah maka berarti tidak termasuk sunah. Seperti soal dzikir berjamaah atau soal administrasi.

Hukum bid'ah menurut Abd Salam, seperti dikutip oleh Hasyim Asy'ari dalam kitab Risalah Ahlussunah Wal Jama'ah, ada lima macam, yaitu: 
1. Bid'ah yang hukumnya wajib, yaitu melaksanakan sesuatu yang tidak pernah dipraktekkan Rasulullah Saw., misalnya mempelajari ilmu nahwu atau mengkaji kata-kata asing (gharib) yang bisa membantu pada pemahaman syari'ah.

2. Bid'ah yang hukumnya haram, seperti aliran Qodariyah, Jabariyah dan Majassimah.

3. Bid'ah yang hukumnya sunah, seperti membangun pemondokan, madrasah (sekolahan), semua itu hal yang baik tidak pernah ada pada periode awal.

4. Bid'ah yang hukumnya makruh, seperti menghiasi masjid berlebihan seperti menyobek-nyobek mushaf.

5. Bid'ah yang hukumnya mubah, seperti berjabat tangan setelah shalat subuh dan asyar, menggunakan tempat makan dan minum yang berukuran lebar, menggunakan ukuran baju yang longgar dan serupa.

Dengan penjelasan bid'ah seperti di atas, Hasyim Asy'ari kemudian mengatakan, memakai tasbih lafadznya niat shalat, tahlilan untuk mayyit, dengan syarat tidak ada yang menghalanginya, ziarah kubut, dan macam-acamnya, itu semua bukanlah bid'ah yang sesat. Adapun pungutan dipasar-pasar malam, main dadu dan lain-lainnya merupakan bid'ah bid'ah yang kurang baik. ${ }^{16}$

\section{E. Tahlilan Sebagai Media Dakwah}

Sejarah tahlilan atau yasinan sebenarnya adalah melalui sejarah panjang terkait dengan proses islamisasi di Jawa yang kemudian menusantara. Menurut para ahli,upacara tersebut diadobsi oleh para ahli terdahulu dari upacara kepercayaan animisme, budhisme dan hinduisme. Menurut kepercayaan animisme, hinduise dan budhiesme bila seseorang meninggal dunia maka ruhya akan datang kerumahnya untuk menjenguk keluarganya. Maka dalam rumah tadi tidak ada orang ramai yang berkumpul-kumpul dan mengadakan upacara-upacara sesaji, seperti membakar kemenyan, dan sesaji kepada yang ghaib, maka ruh tadi akan marah dan masuk (merasup) kedalam jasad yang masih hidup dari keluarga yang mati. Maka untuk itu semalaman para tetangga

${ }^{16}$ AN. Nuril Huda, Ahlussunah Wal Jama'ah. Op.Cit., h. 71-80 
dan kawan-kawan atau masyarakat tidak tidur membaca mantra atau sekedar berkumpul-kumpul. ${ }^{17}$

Menurut Imam Abu Hanifah, Imam Ahmad Ibnu Hanbal dan Shahabat Muta'akhirah dari Imam Syafi'i dan Maliki sepakat bahwa segala bacaan sampai kepada orang mati. Dalam kitab Majmu' Fatawa Imam Ibnu Taimuyyah jilid 24, "Beliau ditanya tentang bacaan keluarga mayyit, tasbih, tahmid, tahlil dan takbir, apalagi dihadiahkan kepada mayyit tentang sampai dan tidaknya pahala tersebut kepada mayat, beliau menjawab, "Bacaan mereka, tasbih dan tahlil apabila dihadiahkan; maka pahalanya akan sampai kepada yang bersangkutan". Ahlu Sunnah berpendapat bahwa segala amal shalih apabila dihadiahkan kepada mayyit, maka pahalanya akan sampai.

Menurut Imam Syafi'i, bahwa al-Qur'an tidak sampai kepada mayyat, yang sampai adalah do'anya. Tetapi Imam Syafi'i muta'akhir telah mentahqiq sampainya bacaan alQur'an kepada mayyit. Menurut Imam Nawawi dalam kitab Al-Majmu', salah satu kitab kitab besar dalam Madzhab Syafi'i, al-Qadli Abu Thayyib ditanya tentang menghkatamkan al-Qur'an dikuburan; maka dia menjawab: "Pahala bagi yang membaca dan juga bagi mayyit sebagaimana para hadirin mengharapkan rahmat dan keberkahan bagi mayyit."

Dengan pengertian demikian, maka tidaklah berlebihan jika disunahkan membaca al-Qur'an dikuburan, dan do'a setelah membaca al-Qur'an lebih dekat untuk diterima. Hikmah membaca al-Qur'an di kuburan ada dua hal. Pertama, mengharapkan datangnya rahmat dan keberkahan bagi mayyit dengan barokah al-Qur'an. Kedua, mengharapkan dikabulkan do'a yang membaca untuk mayyit, karena do'a setelah membaca al-Qur'an lebih dekat untuk dikabulkan. Imam Nawawi dalam kitab al-Adzkar dari jama'ah shahabat Imam Syafi'i bahwa pahala bacaan alQur'an sampai kepada orang mati. ${ }^{18}$

${ }^{17}$ Basyarudin bin Nurdin Shalih Syuhaimin, Membungkar Kesesatan, Op.Cit., h. 23.

${ }^{18}$ AN. Nuril Huda, Aswaja, Op.Cit., h. 113-115 
Pelaksanaan tahlilan adalah tradisi, mengenai boleh dan tidaknya tradisi tersebut para ulama Usuliyyin telah memberikan tuntunan-tuntunan dan ketentuan-ketentuan yang jelas. Dalam kitab Usul al-Fiqh dan Qawa'id Fiqh kita jumpai pembahasan tentang al- 'Urf wa al- 'Adah (tradisi dan kebiasaan). Memang 'urf oleh ulama usul dimasukkan kedalam dalil-dalil yang mukkhtalif 'alaih atau dalil yang masih diperselisihkan diantara para ulama. Namun jumhur ulama, terutama ulama Hanafiyah dan Malikiyah, membolehkan 'urf sebagai dalil atau dasar hukum dengan syarat-syarat tertentu.

Untuk menjawab boleh dan tidaknya tradisi dilakukan, dapat kita ikuti misalnya pembagian 'urf menurut para ulama. 'urf dapat dibagi dalam dua bagian, yaitu 'urf shahih dan 'urf fasid. 'urf shahih adalah adat kebiasaan manusia yang tanpa (tidak samapai) menghalalkan barang haram. Seperti adat kebiasaan mereka bahwa apa yang diberika pelamar kepada yang dilamar, adalah merupakan hadiah dan bukan merupakan mas kawin. Sedangkan 'urf fasid adalah adat kebiasaan manusia, tetapi samapi menghalalkan barang haram atau mengharamkan hal yang halal, seperti kebiasaan manusia memakan riba dan pinjam-meminjam dengan Bank dengan menerima bunga.

Dari penjelasan tersebut dapat kita fahami bahwa 'urf yang dapat dilakukan adalah 'urf shahih (adat kebiasaan yang baik), bukan 'urf fasid (adat kebiasaan yang rusak). Mengenai tradisi tahlilan, kita bisa melihat beberapa segi, diantaranya:

1. Tahlilan merupakan bentuk 'urf shahih (adat kebiasaan yang baik).

2. Sekalipun tidak ada dalil yang membahas tentang pelaksanaan tahlilan, namun juga tidak ditemukan dalil yang melarang tentang pelaksanaan tahlilan.

3. Dalam pelaksanaan tahlilaan tidak ditemukan penghalalan barang haram maupun pengharaman barang halal.

4. Acara pelaksanaan tahlilan tidak bertentangan dengan nash-nash al-Qur'an maupun hadits, bahkan acara tersebut dapat kita temukan dalil-dalilnya, seperti ziarah kubur, majlis ilmi, ajlis dzikir, semaan al-Qur'an, menghadiahkan 
bacaan al-Qur'an atau tahlil atau dzikir kepada orang yang telah mendahului kita.

Tradisi tahlilan merupakan 'urf dalam tinjaun fikih, yang dalam artian bahwa suatu unsure budaya atau tradisi yang keudian dapat dijadikan sebagai dalil dikarnakan tidak keluar dari maqashid al-syari'ah. Pelaksanaan tahlilan bukanlah merupakan syari'ah, namun sebuah budaya atau tradisi local yang diislamisasikan oleh para wali songo ${ }^{19}$ yang dijadikan sebagai media dakwah di nusantara ini.

\section{F. Budaya Lokal yang Dijadikan 'Urf}

\section{Tahlilan}

Tahlilan berasal dari kaliat "hailala yuhaililu tahlîlan" berarti mengucapkan kalimat tauhid. Kata tahlilan ditelinga Masyarakat Muslim Indonesia rasanya sudah tidak asing lagi terutama di kampong-kampung, di desa-desa. Tahlilan sendiri adalah upacara ritual (seremonial) memperingati hari kematian seseorang yang dilakukan oleh masyarakat muslim. Tahlilan ini lebih dapat perhatian di pedesaan daripada diperkotaan. Lebih detailnya lagi tahlilan diadakan ketika sebagian dari anggota keluarga, handai taulan, serta masyarakat sekitar diundang untuk kemudian membaca do'ado'a yang ditunjukkan untuk masyyit yang berada di alam Barzah.

Dikatakan tahlilan karena dari sekian materi (ritual) bacaannya kalimat tahlil (la Ilaha Illallah) mendominasi dan dibaca seccara berulang-ulang sampai ratusan kali. Pada saat yang bersaaan, keluarga yang berkenaan musibah ini meyediakan berbagai hidangan makanan, minuman lebih lagi pada hari ketiga, ketujuh dan seterusnya setelah kematian, jamuan makanan dan minuman seperti layaknya pesta kematian. Menu makanan tersebut pada hari ketiga, ketujuh,

${ }^{19}$ Walisongo yaitu nama yang terkenal untuk menyebut namanama tokoh yang dipandang sebagai mula pertama penyiar agama Islam di Tanah Jawa. Ridin Sufyan, Islamisasi di Jawa, (Yogyakarta: Pustaka Pelajar, 2000), h. 7 
keempat puluh lebih dari biasanya lebih diutamakan atau bahkan dianjurkan untuk menjamu orang yang berkumpul. ${ }^{20}$

Tahlilan atau upacara selamatan untuk orang yang telah meninggal, biasanya dilakukan pada hari pertama kematian sampai pada hari ketujuh, selanjutnya dilakukan pada hari ke40, ke-100 pada tahun pertama, kedua, ketiga dan seterusnya. Dan ada juga yang melakukan pada hari ke-1000 dalam upacara tersebut, keluarga si mayit mengandung orng yang membaca beberapa ayat dan surat al-Qur'an dan dzikir mulut tersebut dihadiahkan pada si mayit. ${ }^{21}$

\section{Yasinan}

Yasinan berasal dari kalimat dari kata "yâsîn". Membaca surat tersebut pada hari yang sama dan jam sama disebut dengan yasinan, karena akhiran "an" dari kata yasinan, mengandung arti pekerjaan yang selalu dilakukan secara berulang-ulang pada hari yang sama. ${ }^{22}$ Allah Swt., menurunkan kitab suci al-Qur'an kepada Nabi Muhammad Saw., terdiri dari 114 surat yang kesemuanya, wajib dipelajari, dibaca, dikaji serta ditadaburi isinya. Suratb yasin terdiri dari atas 83 ayat, surat yang ke-36 dari urutan 114 surat yang ada dalam al-Qur'an yang 30 juz. ${ }^{23}$

Yâsîn yaitu surat yang diawali dengan huruf-huruf terputus (al-huruf al-munqatha'ah), yang terdiri dari huruf yâ dan sîn, yang disambung menjadi yâsîn. Sebagian mufassir klasik menafsirkannya dengan pernyataan "Allah lebih mengetahui tentang maksudnya". Menyerahkan maksud tersebut kepada Allah Swt.

Menurut al-Syaikh Sayyid Quthb dalam tafsir Dzilalnya menjelaskan secara lebih dalam (tadabbut) bahwa hurufhuruf yang terputus yang menjadi pebuka beberapa surat dalam al-Qur'an, mengandung pesan Allah di satu sisi bahwa wahyunya tersusun dari rangkaian huruf-huruf tersebut. Sedangkan, disisi lain sebagai tantangan yang melemahkan (I’jaz) orang-orang kafir untuk membuat susunan kalimat

${ }^{20}$ Basyarudin bin Nurdin Shalih Syuhaimin, Membungkar

Kesesatan, (Bandung: CV. Mujahid Press, 2007), h. 24

${ }^{21}$ Ibid., h. 25

${ }^{22}$ Ibid., h. 79

${ }^{23}$ Ibid., h. 75 
yang sama dengan wahyu Allah (al-Qur'an), karena seharihari mereka berbicara, juga merangkai kata-kata, sya'ir, dan tulisan huruf-huruf tersebut. Oleh karena itu, mereka ditantang oleh Allah Swt.

Apakah dengan bahan baku mereka dapat membuat kata-kata dan kalimat yang semisal ayat-ayat al-Qur'an. Sebagaimana yang ditegaskan oleh Allah Swt. surat alBaqarah ayat 23, sebagai berikut:

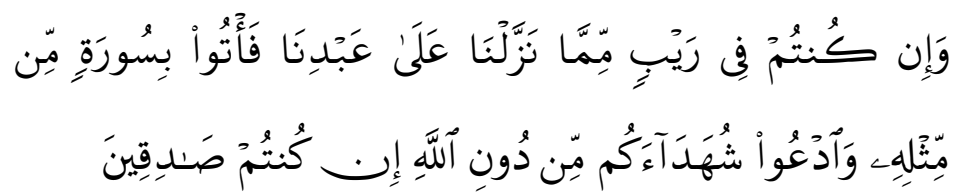

Artinya: "Dan jika kamu (tetap) dalam keraguan tentang Al Quran yang Kami wahyukan kepada hamba Kami (Muhammad), buatlah satu surat (saja) yang semisal Al Quran itu dan ajaklah penolong-penolongmu selain Allah, jika kaтu orang-orang yang benar. (QS. al-Baqarah: 23).

Ayat ini merupakan tantangan bagi mereka yang meragukan kebenaran al-Qur'an dan bahwa kebenaran tersebut tidak dapat dituru walaupun dengan mengerahkan semua ahli sastra dan bahasa. Karena itu, ia merupakan mu'jizat Nabi Muhammad Saw.

Sebagian mufassir lainnya menafsirkan yâsîn dengan yâ sîn dengan yâ insan!, yang artinya, "Wahai Manusia!" maksudnya, Allah menyerukan manusia untuk memperkatikan ayat-ayat setelahnya yang banyak menyinggung tentang masalah-masalah keimanan kepada Allah, Rasul, al-Qur'an dan negeri akhirat. Ada juga yang mengartikan sebagai nama lain dari nama Muhammad Saw., sebagaimana tertuang dalam salah satu bacaan shalawat.

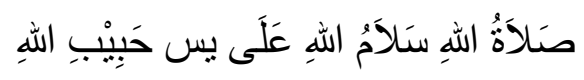

Artinya: "Salam sejahtera dari Allah untuk Nabi Muhammad (Yasiin) kekasih Allah". ${ }^{24}$

${ }^{24}$ Muhammad Sa'id, Pesona Surat Yasin, (Jakarta: Gema Insani, 2008), h. 21-23 


\section{Istighasah}

Asal kata istighasah adalah al-ghauts () yang berarti () permintaan pertolongan. Sebagian ulama membedakan antara istighasah dan isti'anah, demikian dari sisi kebahasaan keduanya mempunyai makna yang sama. Sebagaimana ditegaskan Imam Taqiyyuddin al-Subki dalam Syifa' alSaqam, bahwa istisfa', tawassul, istighasah, isti'anah, tawajjuh dan tajawwuh makna dan hakekatnya adalah satu.

Beberapa dalil tentang kebolehan melakukan tawassul dan istighasah, sebagai berikut:

a. Hadits tentang orang buta yang datang kepada Rasulullah. Hadits ini diriwayatkan oleh al-Thabari dalam Mu'jam alKabir dan Mu'jam al-Shahir. Juga diriwayatkan oleh alTurmudzi, al-Hakim dan lainnya. ulama muta'akhirin juga membenarkan hadits tersebut, seperti al-Hafidz al-Nawawi dan al-Hafidz ibnu al-Jazari. Makna hadits tersebut menunjukkan dibolehkannya bertawashul dengan para Nabi dan Para Wali, selagi masih hidup atau sudah mati. Dengan demikian, hal ini membantah bahwa tawassul hanya dengan al-hay al-hadir dengan meminta do'anya.

b. Hadits yang diriwayatkan oleh Ibnu Majah dan Sunan-nya, ia berkata, dari Sa'id al-Khudri Rasulullah Saw., bersabda:

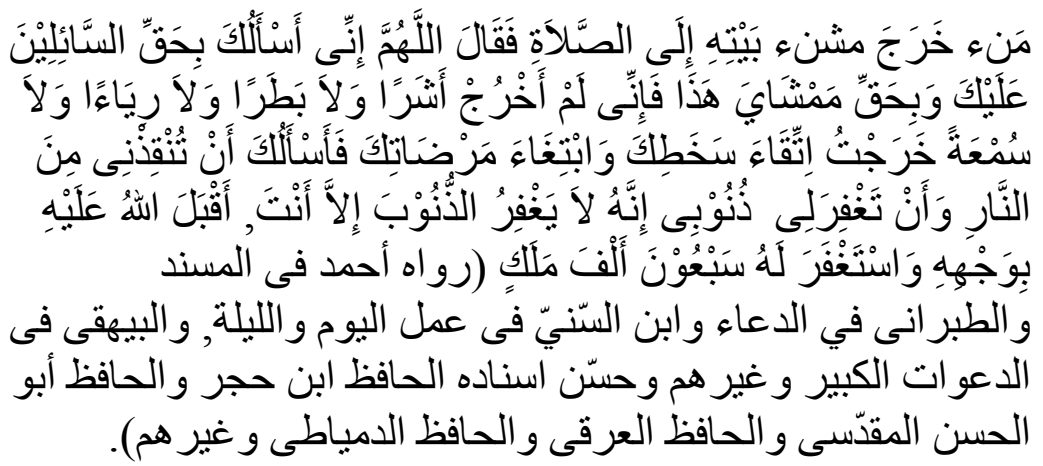

Artinya: "barang siapa yang keluar dari rumahnya untuk shalat di masjid kemudian ia berdo'a; Ya Allah Sesungguhnya aku memohon kepada-Mu dengan derajat orang-orang yang shalih yang berdo'a kepada-Mu (baik yang masih hidup maupun yang sudah mati) dan derajat langkah-langkahku ketika berjalan ini, sesungguhnya aku 
keluar rumah bukan untuk menunjukkan rasa angkuh dan sombong, dan juga bukan karena riya' dan sum'ah akau keluar rumah untuk menjauhi murka-Mu dan mencari ridhaMu, maka aku memohon kepada-Mu; selamatkanlah aku dari api neraka dan ampunilah dosa-dosaku, sesungguhnya tidak ada yang mengampuni dosa keculi Engkau, maka Allah akan meridhainya dan tujupuluh malaikat memohon ampun untuknya".

c. Hadits diriwayatkan oleh al-Baihaqi, Ibnu Abi al-Syaibah, dan yang lainnya:

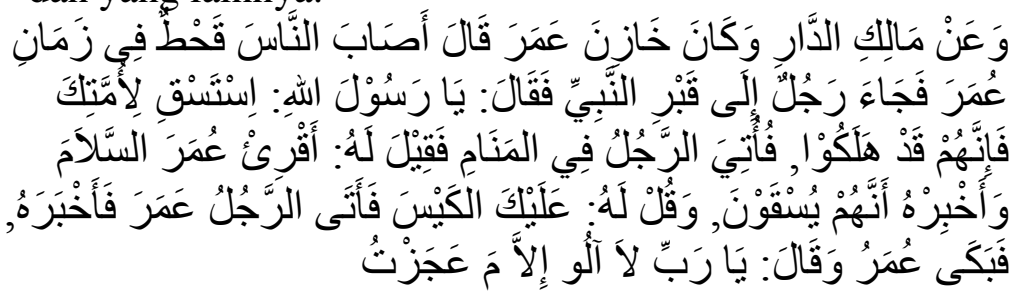

Artinya: "Peceklik datang di masa Umar, maka datang salah seorang sahabat yaitu Bilal Ibnu Harits al-Muzani mendatangi kuburan Nabi dan mengatakan; Wahai Rasulullah, mohonkanlah hujan untuk umat-mu, karena mereka telah betul-betul binasa kemudian orang tersebut bermimpi ketemu dengan Rasul dan Rasul berkata kepadanya; "Sampaikan salamku untuk Umar dan hujan akan turun untuk mereka, dan katakana kepadanya bersungguh-sungguhlah dalam melayani umat". Kemudian sahabat tersebut datang kepada Umar dan memberitahukannya apa yang dilakukannya dan mimpi yang dialaminya. Umar menangis dan mengatakan; "Ya Allah, aku akan kerahkan semua upayaku kecuali apa yang aku tidak mampu”.

d. Hadits yang diriwayatkan oleh al-Thabrani, dari Abbas bahwa Rasulullah Saw., bersabda:

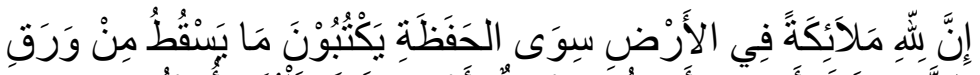

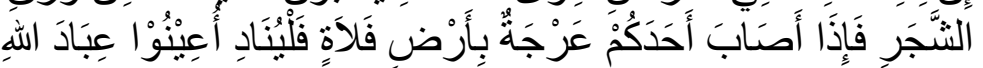

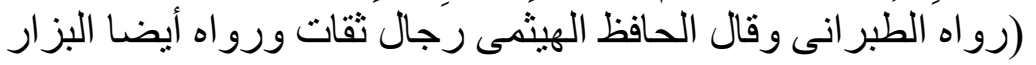

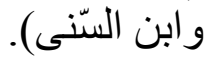


Artinya: "Sesungguhnya Allah memiliki para malaikat di bumiselain hafadzhah yang menulis daun-daun yang berguguran, maka jika kalian ditimpa disuatu padang maka hendaklah mengatakan, tolonglah aku wahai para hamba Allah".

Al-Nawawi telah meriwayatkan dari Ibnu Sunni dalam kitab al-Adzkar mengatakan: "Sesungguhnya dari guruguruku yang sangat alim pernah menceritakan bahwa pernah lepas hewan tunggangannya dan beliau mengetahui hadits ini lalu beliau mengucapkan dan seketika hewan tunggangannya tersebut berhenti berlari.

e. Hadits yang diriwayatkan oleh Bukhari dan Muslim dari Abu Hurairah, Rasulullah Saw., bersabda; bahwa Nabi Musa berdo'a:

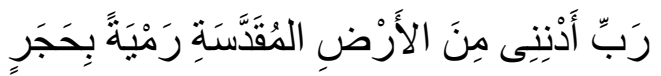

Artinya: "Ta Allah dekatkanlah aku ke tanah bayt alMaqdis meskipun sejauh lamparan batu".

Kemudian Rasulullah bersabda :

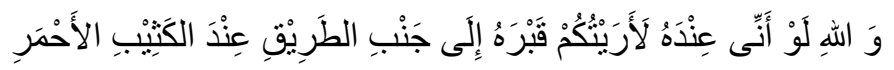

Artinya: "Demi Allah, jika aku berada di dekat kuburan Nabi Musa niscaya akan aku perlihatkan kuburannya di samping jalan di daerahal-Katsib al-Ahmar".

Komentar al-Hafidz Waliyuddin al'Iraqi, dalam kitabnya Syarh al-Tasyrib, dalam hadits ini terdapat dalil kesunahan untk mengetahui kuburan orang-orang yang shalih untuk berziarah kesana dan memenuhi hak-haknya.

Telah menjadi tradisi dikalangan ulama Salaf dan Khalaf bahwa ketika mereka menghadapi kesulitan atau ada keperluan mereka mendatangi kuburan orang-orang shalih untuk berdo'a disana dan mengambil barokahnya dan setelahnya do'a mereka dikabulkan oleh Allah. Imam alSyafi'i ketika ada hajat yang ingin dikabulkan seringkali mendatangi kuburan abu Hanifah dan berdo'a disana dan setelahnya dikabulkan oleh Allah. Dikatakan al-Hafidz Syamsuddin ibnu Jazari dalam kitab 'Uddahal-Hisn alHashin disebutkan: 


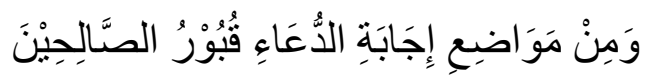

Artinya: "Diantara tempat dikabulkannya do'a adalah kuburan orang-orang yang shalih".

Al-Hafidz ibnu al-Jazari sendiri sering mendatangi kuburan Imam Muslim ibnu al-Hajjaj, penulis kitab shahih Muslim dan berdo'a disitu seperti diceritakan oleh Ali al-Qari dalam Syarh Misykat. Dengan demikian, mengucapkan Tawassul dan istighassah adalah amalan para ulama ahli hadits dan yang lainnya. ${ }^{25}$

\section{Tawassul}

Washilah artinya sesuatu yang menjadikan kita dekat kepada Allah Swt. adapun tawassul sendiri artinya mendekatkan diri kepada Allah atau berdo'a kepada Allah dengan menggunakan perantara (washilah). Pernyataan demikian dapat dilihat dalam surat al-Ma'idah ayat 35, sebagai berikut:

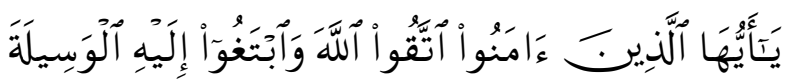

Artinya: "Hai orang-orang yang beriman, bertakwalah kepada Allah dan carilah jalan (washilah/perantara)". (alMa'idah: 35).

Tawasul dengan washilah amal diantaranya ialah:

a. Iman sebagai washilah yang menjadikan manusia dekat kepada Allah Swt.

b. Ibadah dan amal kebajikan dapat menjadi washilah yang mendekatkan diri kepada Allah.

c. Amar ma'ruf nahi munkar juga menjadi washilah yang mendekatkan diri kepada Allah. Karena itu, berdo'a dengan memakai washilah di atas tidak ada ulama yang menyalahkan, artinya telah disepakati kebolehannya.

Tawashul dengan orang-orang yang dekat kepada Allah, para Nabi, para Rasul, sahabat-sahabat Rasul Saw., para Tabi'in, para Shuhada' dan para Ulama Shalihin tidak ada larangan dalam ayat al-Qur'an dan Hadits. Bertawashul dengan orang-orang yang dekat kepada mereka yang

${ }^{25}$ Ahlussunah Wal Jama'ah (Aswaja) Menjawab Persoalan

Tradisi dan Kekinian, (Jakarta: Gaung Persada, 2007), h. 141-147 
dijadikan washilah, senyatanya washilah itu tetap memohon kepada Allah Swt., karena Allah tepat meminta dan harus diyakini bahwa sesungguhnya:

\section{لا مَانِعَ لِمَا أَعْطَيَتَ وَلَا مُعْطِى لِلمَا مَنَعْتَ}

Artinya: "Tidak ada yang dapat mencegah terhadap apa yang Engkau (Allah) berikan, dan tidak ada yang bisa memberi sesuatu apabila Engkau (Allah) mencegahnya".

Bertawashul dengan orang-orang yang dekat kepada Allah $S w t$., itu agar mereka ikut memohon kepada Allah $S w t$., atas apa yang diminta kepada Allah. Dngan begitu, maka dalam hal itu tidak ada unsur-unsur musyrik. Jika bertawashul dengan orang-orang yang dekat kepada Allah Swt., seperti para Nabi, para Rasul dan para Shalihin, pada hakekatnya tidak bertawashul kepada dzat ereka, tetapi bertawashul dengan amal perbuatan mereka yang shalih. Karenanya, bertawashul itu tidak dengan orang-orang yang ahli maksiat, pendosa dan menjauhkan diri dari Allah, dan juga tidak bertawashul dengan pohon, batu, gunung dan lainlainnya.

Kembali pada keyakinan kita, bahwa orang yang mati, rusak dan hancur adalah badannya atau jasadnya, bukan ruhnya. Sedangkan ruhnya tetaplah hidup dan tidaklah mati. Sebab mereka berada di alam barzakh. Mereka telah terputus segala amalnya untuk diri mereka. Dalam kitab Shahih Muslim juz 2, disebutkan:

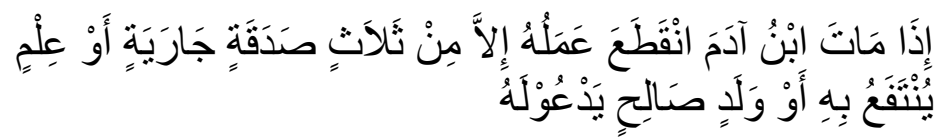

Artinya: "Apabila manusia telah mati, maka terputuslah darinya amalnya, kecuali tiga; shadaqah jariyah, atau ilmu yang bermanfaat atau anak shalih yang mendo'akan".

Hadits diatas menjelaskan bahwa apabila manusia telah meninggal dunia itu putus atas segala amalnya untuk dirinya sendiri, tetapi untuk orang lain, misalnya ahli kubur mendo'akan orang yan didunia tidak ada keterangannya yang 
melarang. ${ }^{26}$ Segala macam cara yang mengandung unsure permohonan kepada Allah Swt., dan minta bantuan (syafa'at), yang dapat memperkuat terkabulnya do'a, dengan syarat menghindarikeyakinan, ucapan, maupun perbuatan yang tidak sesuai dengan tuntunan agama. ${ }^{27}$

\section{G. Hukum Tahlilan}

Upacara Tahlilan umumnya diselenggarakan dengan acara berupa ziarah al-Qabri, Majlis al-Ilmi, Majlis al-Dzikr, sema'an al-Qur'an, mendo'akan orang yang sudah meninggal, sebagai bentuk birrul walidain, silaturahim dan sebagainya. Upacara yang belum pernah terjadi di Masa Rasulullah Saw., dan para sahabatnya itu ternyata banyak mendapat tanggapan berbeda-beda, ada yang menganggap baik, ada juga yang menganggap buruk. ${ }^{28}$

Berkaitan dengan doa dan pahala yang diberikan kepada orang yang telah meninggal, sabda Rasulullah Saw., sebagai berikut:

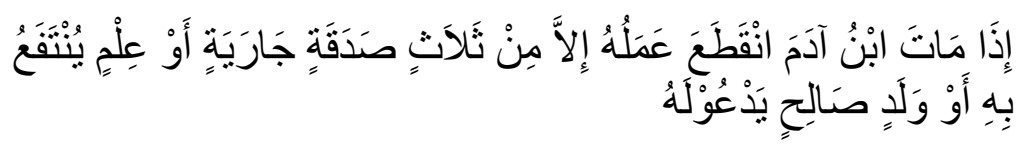

Artinya: "Apabila anak Adam mati, maka putuslah segala amal perbuatannya kecuali tiga perkara; yaitu shadaqah jariyah, ilmu yang bermanfaat, dan anak shalih yang mendoakan orang tua".

Firman Allah $S w t$. , sebagai berikut:
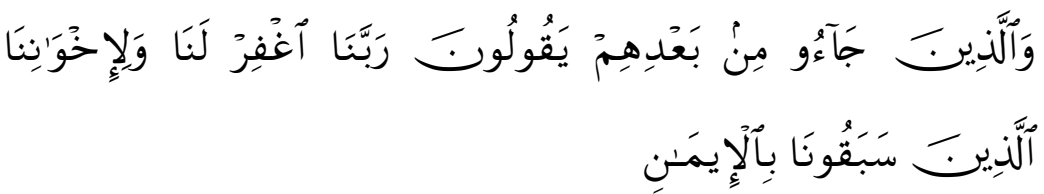

Artinya: "Dan orang-orang yang datang sesudah mereka (Muhajirin dan Anshor), mereka berdoa: "Ya Rabb Kami, beri ampunlah Kami dan saudara-saudara Kami yang

${ }^{26}$ AN. Nuril Huda, Aswaja, Op.Cit., h. 127-130.

${ }^{27}$ Kang Santri, Menyikapi Problematika Umat, (Kediri: Team Kang Santri, 1999), h. 399

${ }^{28}$ Asyhari Marzuki, Wawasan Islam Menggapai Kehidupan alQur'ani, (Yogyakarta: Nurma Media Idea, 2003), h. 90 
telah beriman lebih dulu dari Kami, dan janganlah Engkau membiarkan kedengkian dalam hati Kami terhadap orangorang yang beriman" (QS. al-Hayr: 10).

Dalam hal ini, hubungan antara sesama orang mukmin tidaklah putus dari dunia samapi pada akhirat.

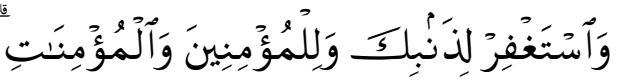

Artinya: "Dan mohonlah ampunan bagi dosamu dan bagi (dosa) orang-orang mukmin, laki-laki dan perempuan". (QS. Muhammad: 19)

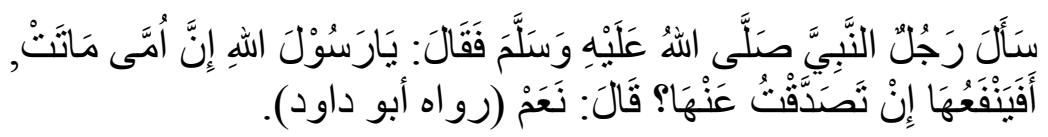

Artinya: "Bertanya seorang Nabi kepada Rasulullah Saw., Ya Rasulullah sesungguhnya ibu saya telah meninggal, apakah berguna bagi saya, seandainya saya bersedekah untuknya? Rasulullah Saw., menjawab; ya, berguna untuknya”. (HR. Abu Daud).

Dan masih banyak juga dalil-dalil yang memperkuat bahwa yang mati masih mendapat manfaat do'a perbuatan orang lain. Seperti firman Allah Swt., sebagai berikut:

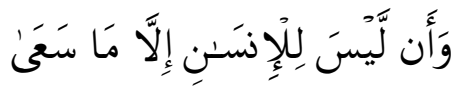

Artinya: "Dan bahwasanya seorang manusia tiada memperoleh selain apa yang telah diusahakannya". (QS. alNajm: 29).

Maksud dari ayat tersebut adalah bahwa secara umum yang menjadi hak seorang adalah apa yang dikerjakan, sehingga orang tidak menyandarkan kepada perbuatan orang. Tetapi, makna ayat ini tidak berarti menghilangkan perbuatan seorang untuk orang lain. Di dalam tafsir alThabari jilid 9 juz 27 menjelaskan bahwa ayat tersebut diturunkan tatkala Walid Ibnu Mughirah masuk Islam diejek oleh orang musyrik, dan orang musyrik tadi berkata: "Kalau engkau kembali kepada agama kami dan memberi uang kepada kami, kami yang akan menanggung siksamu diakhirat”. 
Maka Allah Swt., menurunkan ayat tersebut yang menunjukkan bahwa seorang tersebut tidak bisa menanggung dosa orang lain, bagi seseorang apa yang ia kerjakan, bukan berarti menghilangkan pekerjaan seorang untuk orang lain, seperti do'a orang yang telah mati dan sebagainya.

Dalam tafsir al-Thabari jugta dijelaskan, dari sahabat Ibnu Abbas; bahwa ayat tersebut telah diansukh:

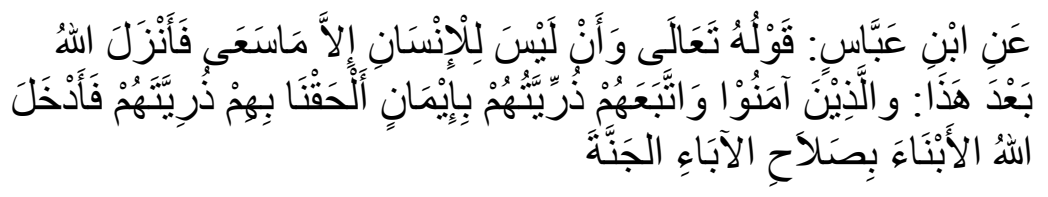

Artinya: "Dari sahabat Ibnu Abbas dalam firman Allah Swt., tidak bagi seorang kecuali apa yang telah dikerjakan, kemudian Allah Swt., menurunkan surat ayat al-Thur; 21. Dan orang-orang yang beriman, dan yang anak cucu mereka mengikuti mereka dalam keimanan, kami pertemukan anak сиси mereka, maka Allah memasukkan anak cucu mereka, maka Allah memasukkan anak kecil ke surge karena kebaikan orang tua".

Menurut Ibnu Taimiyyah dalam kitab Majmu' Fatawa jilid 24, berkata: “Orang yang berkata bahwa do'a tidak sampai kepada orang mati dan perbuatan baik pahalanya tidak sampai kepada orang mati" mereka itu ahli bid'ah sebab para ulama telah sepakat bahwa mayyit mendapat manfaat dari do'a dan amal shalih orang yang hidup. ${ }^{29}$

Selain do'a kepada orang yang sudah meninggal, maka termasuk perkara shadaqah untuk orang yang meninggal. Salah satunya adalah ketika masih hidup seseorang mempunyai keinginan ('azam) tapi ia belum melaksakannya karena keburu meninggal, dipanggil yang Kuasa atau sebab lainnya, karena anak atau kerabatnya merasa mampu secara ekonomi dan ingin bershadaqah atas nama orang yang sudah mati tersebut. Hal ini pernah terjadi pada masa Rasulullah Saw., sebagai berikut:

${ }^{29}$ AN. Nuril Huda, Aswaja, Op.Cit., h. 93-95 


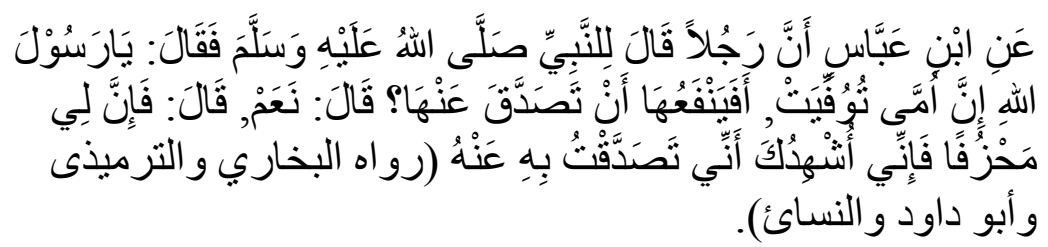

Artinya: "Dari sahabat Ibnu abbas ra., bahwa seorang laki-laki datang kepada Nabi Saw, berkata; sesungguhnya ibu saya meninggal, apakah ada manfaatnya apabila saya menyedekahkan untuk ibu saya? Rasulullah menjawab; ya berguna bagi ibumu; orang itu berkata; sebenarnya saya mempunyai sebuah kebundan engkau ya Rasulullah saya jadikan saksi, dan aku telah menyedahkan kebut itu untuk ibu saya". (HR. Al-Bukhari, Tirmidzi, Abu Daud dan Nasa'i).

Hadits Rasulullah dari Aisyah ra., sebagai berikut:

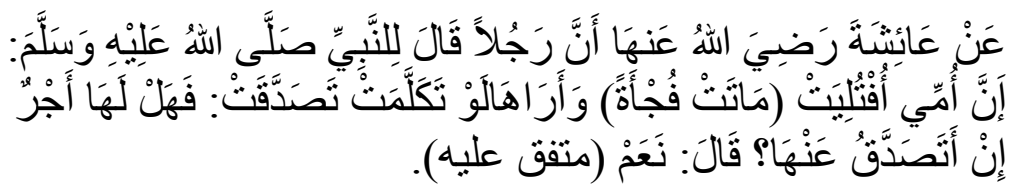

Artinya: "Dari siti Aisyah ra., bahwa seorang laki-laki berkata kepada Nabi Muhaad Saw., sesungguhnya ibu saya mati mendadak, dan saya yakin seandainya ia bisa bicara, dia bershodaqah, apakah ibu saya mendapat pahala, seandainya saya bershadaqah untuk ibu saya? Rasulullah menjawab; ya ada pahala buat ibumu".

Dengan demikian, tidak usah khawatir bahwa niat bersedekah yang diniatkan khusus untuk orang yang meninggal dunia itu tidak akan sampai kepada yanbersangkutan, sebab Rasulullah sendiri menjawab demikian. Diakhirat nanti Rasulullah sendiri yang akan menjadi saksi dihadapan Allah $S w t .^{30}$

${ }^{30}$ AN. Nuril Huda, Aswaja, Op.Cit., h. 101-103. Lihat juga Ibnu Hajar al-Haitami, al-Fatawa al-Fiqh al-Kubra, jilid II, (Mesir: alMaktabah al-Islamiyyah, tt.), h. 18. Lihat juga PBNU, Solusi Problematika Aktual Hukum Islam, (Surabaya: Khalista, 2010), h. 326. Lihat juga al-Imam al-Faqih al-Muhaddits Muhyiddin Abi Zakariyya Yahya bin Syaraf al-Nawawi al-Dimasyqy, Al-Adzkar, (Semarang: Toha Putra, tt.), h. 119 


\section{H. Kesimpulan}

Suatu tradisi ('urf) bisa dilaksanakan apabila tidak bertentangan dengan ajaran syari'ah. Dalam artian, bahwa tidak semua tradisi dapat dijadikan sebagai sumber hukum Islam, yaitu yang biasa disebut sebagai (bid'ah dhalalah). Adapaun tradisi itu sendiri merupakan suatu kegiatan yang berulang-ulang dilakukan yang kemudian menjadi adat istiadat, namun tidak melanggar tatanan syari'ah , dan tradisi bukan merupakan syari'ah, namun sebgai cabang (furu') dalam rangka menyikapi atau bahkan mengembangkan ajaran Islam secara amaliyah atau sering disebut (bid'ah hasanah).

Para ahlu sunnah wal jama'ah mengembangkan budaya lokal tersebut seperti tahlilan, yasinan, istighasah, tawashul atau sejenisnya secara pelaksanaan (praktek) tidak ada aturannya yang baku, namun justru pelaksanaan tersebut lebih menekankan kepada bacaan tahlilnya (la ilaha ilallah), atau yasinan yaitu bacaan yasinnya sebagai qalbu qur'an, istighasahnya yaitu memohong pertolongan kepada Allah dan bukan selainnya, serta tawashul yaitu bentu ihtiram kepada guru sebagai washilah dalam sebuah do'a, dan tentunya inilah bid'ah hasanah bukan ajaran yang keluar dari syara'.

\section{Daftar Pustaka}

Abdullah bin Abdul Aziz al-Tuwaijiry, al-Bida'i alHauliyyah wa Fatwa Tata'allaq bi al-Maulid alNabawi, diterjemahkan oleh Munirul Abidin, Jakarta: Daril Falah, 2007

Abdul Qayyum Muhammad al-Sahibani, al-Lam'u fi al-Radi 'Ala Muhsiniy al-Bid'ah, diterjelahkan oleh Abu Hafh Muhammad Syarif Asbi Al-Anboniy, Solo: al-Tibyan, 2003

Abdul Wahab Khalaf, Kaidah-Kaidah Hukum Islam, diterjemahkan oleh Noer Iskandar, Jakarta: Rajawali Press, 1996

Ahmad bin Ali al-Mubaraki, al-'Urf wa Atsaruhu fi alSyari'ah wa al-Qonun, dikutip oleh Asmawi, Jakarta: Amzah, 2011 
Anis bin Ahmad bin Thahir, Dhawabit Muhimmah li Husni Fahmi al-Sunnah, diterjeahkan oleh Abu Abdirrahman Mukti 'Ali Abdul Karim, Bogor: Pustaka Imam AlSyafi'i, 2004

Asyhari Marzuki, Wawasan Islam Menggapai Kehidupan alQur'ani, Yogyakarta: Nurma Media Idea, 2003

Basyarudin bin Nurdin Shalih Syuhaimin, Membungkar Kesesatan, Bandung: CV. Mujahid Press, 2007

Chairul Umam dkk, Ushul Fiqh I, Bandung: Pustaka Setia, 2008

Huzaimah Tahido Yanggo, Pengantar Perbandingan Madzhab, Ciputat: Gaung Persada Press, 2011

Ibnu Hajar al-Haitami, al-Fatawa al-Fiqh al-Kubra, jilid II, Mesir: al-Maktabah al-Islamiyyah, tt.

al-Imam al-Faqih al-Muhaddits Muhyiddin Abi Zakariyya Yahya bin Syaraf al-Nawawi al-Dimasyqy, Al-Adzkar, Semarang: Toha Putra, tt.

Kang Santri, Menyikapi Problematika Umat, Kediri: Team Kang Santri, 1999

Muhammad Sa'id, Pesona Surat Yasin, Jakarta: Gema Insani, 2008

Nahdhatul Ulama, Faham Keagamaan dan Ideologi Kenegaraan Nahdhatul Ulama', Mojokerto: PC Nahdhatul Ulama' Kabupaten Mojokerto, 2006 